\title{
Recent Changes in Serological Markers of Hepatitis B Virus Infection in Japanese University Students
}

\author{
Shozo Nakamura \\ Tohoku University Health Center, Sendai 980
}

\begin{abstract}
Nakamura, S. Recent Changes in Serological Markers of Hepatitis B Virus Infection in Japanese University Students. Tohoku J. exp. Med., 1985, 147 (2), 213-216 — University students were screened for serological markers of hepatitis $B$ virus infection every year. Hepatitis B surface antigen ( $\mathrm{HBsAg}$ ) determined by reversed passive hemagglutination and antibody to $\mathrm{HBsAg}$ (anti-HBs) by passive hemagglutination were positive in $1.7 \%$ and $7.3 \%$ of the first-year students in 1978-80, respectively, and $1.1 \%$ and $3.8 \%$ in 1981-84. The difference in the prevalences of anti-HBs between 1978-80 and 1981-84 was statistically significant $(p<0.001)$. Hepatitis B e antigen, which was positive by less sensitive immunodiffusion in $52 \%$ of HBsAg carrier students in 1976-79, was detected by more sensitive radioimmunoassay only in $19 \%$ in 1980-84. The difference was statistically significant $(p<0.01)$. Recently changes in hepatitis B virus infection seem to be occurring in Japanese university students. —— changes in hepatitis B virus infection; hepatitis B surface antigen; antibody to hepatitis B surface antigen; hepatitis B e antigen; Japanese university students
\end{abstract}

The prevalences of serological markers of hepatitis $\mathrm{B}$ virus infection in apparently healthy adults in Japan are intermediate between those in the other Asian and African countries and those in West Europe and the United States, and hepatitis B virus infection presents not a small problem in health care of young adults in Japan. We have been studying serological markers of hepatitis B virus infection in students of a university located in the northern part of Japan (Nakamura 1978, 1982, 1983). Recently interesting changes seem to be occurring in these university students. The results will be described.

\section{Subjects and Methods}

Since 1973 students, mainly of medicine and related science, of Tohoku University were screened for serological markers of hepatitis B virus infection every year. The students totaled 5680. 3537 were males, and 2143 females. Hepatitis B surface antigen (HBsAg) was determined by single radial immune diffusion (Eisai Plate ; Eisai Co., Tokyo) in 197376 and by reversed passive hemagglutination (RPHA) (AUSCELL; Abbott Laboratories, North Chicago, Ill., USA) in 1976-84. Antibody to HBsAg (anti-HBs) was measured by passive hemagglutination (PHA) (Hebsgencell; Midori-juji Co., Osaka) in 1977-84. Hepatitis $\mathrm{B}$ e antigen ( $\mathrm{HBeAg}$ ) and antibody to $\mathrm{HBeAg}$ (anti-HBe) were detected by

Received June 13, 1985 ; accepted for publication August 7, 1985. 
immunodiffusion (ID) in 1976-79, and by radioimmunoassay (RIA) (HBe ; Abbott Laboratories) in 1980-84. Subtypes of HBsAg were tested by hemagglutination inhibition (Imai et al. 1974) and by RIA (Ise et al. 1982). Determination of HBeAg and anti-HBe by ID and of HBsAg subtypes was carried out at Hepatitis Division of Tokyo Metropolitan Institute of Medical Science. Comparisons of proportions were analyzed by Fischer's exact test or $\chi^{2}$-test.

\section{Results}

HBsAg was positive in $86(1.5 \%)$ of the 5,680 students $(1.7 \%$ of males and $1.2 \%$ of females). The results of the first-year students in whom HBsAg was determined by RPHA and anti-HBs by PHA are shown in Table 1. Though the difference of prevalences of HBsAg between 1978-80 and 1981-84 (1.7\% vs. 1.1\%) was not statistically significant, the prevalence of anti-HBs in 1981-84 (3.8\%) was significantly lower than that in $1978-80(7.3 \%)(p<0.001)$. The prevalence of both hepatitis B virus markers in 1981-84 $(4.9 \%)$ was also significantly lower than that in $1978-80(9.0 \%)(p<0.001)$. Differences in the prevalences of anti-HBs and of both hepatitis B virus markers were statistically significant in male students $(p<0.001)$, but not in females.

The results of the initial determination of $\mathrm{HBeAg}$ and anti-HBe in $\mathrm{HBsAg}$ carrier students are shown in Table 2. $\mathrm{HBeAg}$, which was positive by less sensitive ID assay in $52 \%$ of the carrier students in $1976-79$, was detected by RIA only in $19 \%$ in $1980-84$. The difference was statistically significant $(p<0.01)$. The difference was also statistically significant in male carrier students $(p<0.05)$, but not in females.

Of $27 \mathrm{HBsAg}$ carrier students born in or before 1960, 52\% showed subtype $a d r$ and $48 \% a d w$. Of 16 carrier students born after 1960, 50\% had $a d r$ and $50 \%$ $a d w$. There was no significant difference.

During their school days, $0.3 \%$ of the previously seronegative students became positive for anti-HBs annually. None of the previously seronegative students became positive for $\mathrm{HBsAg}$. Of $15 \mathrm{HBeAg}$-positive $\mathrm{HBs}$ g carrier

TABLE 1. Serological markers of hepatitis B virus infection in the first-year students

\begin{tabular}{cccccc}
\hline $\begin{array}{c}\text { Year of } \\
\text { entrance }\end{array}$ & Sex & Number & $\begin{array}{c}\text { HBsAg } \\
\text { poitive } \\
\text { by RPHA }\end{array}$ & $\begin{array}{c}\text { Anti-HBs } \\
\text { positive } \\
\text { by PHA }\end{array}$ & $\begin{array}{c}\text { HBsAg or } \\
\text { anti-HBs } \\
\text { positive }\end{array}$ \\
\hline \multirow{2}{*}{$1978-80$} & $\mathrm{M}$ & 586 & $12(2.0 \%)$ & $45(7.7 \%)$ & $57(9.7 \%)$ \\
& $\mathrm{F}$ & 380 & $4(1.1 \%)$ & $26(6.8 \%)$ & $30(7.9 \%)$ \\
& $\mathrm{M}+\mathrm{F}$ & 966 & $16(1.7 \%)$ & $71(7.3 \%)$ & $87(9.0 \%)$ \\
\hline $1981-84$ & $\mathrm{M}$ & 913 & $8(0.9 \%)$ & $28(3.1 \%)^{*}$ & $36(3.9 \%)^{*}$ \\
& $\mathrm{~F}$ & 699 & $9(1.3 \%)$ & $34(4.9 \%)$ & $43(6.2 \%)$ \\
& $\mathrm{M}+\mathrm{F}$ & 1612 & $17(1.1 \%)$ & $62(3.8 \%)^{*}$ & $79(4.9 \%)^{*}$ \\
\hline
\end{tabular}

* $p<0.001$ for difference from those in 1978-80. 
TABLE 2. Results of the initial determination of $H B e$ and anti-HBe in HBsAg carrier students

\begin{tabular}{ccccccc}
\hline Year & Method & Sex & Number & $\begin{array}{c}\text { HBeAg } \\
\text { positive }\end{array}$ & $\begin{array}{c}\text { Anti-HBe } \\
\text { positive }\end{array}$ & $\begin{array}{c}\text { Negative } \\
\text { to both }\end{array}$ \\
\hline \multirow{2}{*}{$1976-79$} & ID & M & 21 & $12(57 \%)$ & $6(29 \%)$ & $3(14 \%)$ \\
& & M $+\mathrm{F}$ & 31 & $16(52 \%)$ & $9(29 \%)$ & $6(19 \%)$ \\
\hline \multirow{3}{*}{$1980-84$} & \multirow{2}{*}{ RIA } & M & 29 & $7(24 \%)^{*}$ & $20(69 \%)$ & $2(7 \%)$ \\
& & F & 13 & $1(8 \%)$ & $12(92 \%)$ & $0(0 \%)$ \\
& & M $+\mathrm{F}$ & 42 & $8(19 \%) \dagger$ & $32(76 \%)$ & $2(5 \%)$ \\
\hline
\end{tabular}

* $p<0.05$ for difference from that by ID in 1976-79.

$\dagger p<0.01$ for difference from that by ID in 1976-79.

students, $4(27 \%)$ cleared HBeAg during 3 years of observations, and $3(20 \%)$ seroconverted to anti-HBe. Six $(7 \%)$ of the $86 \mathrm{HBsAg}$ carrier students showed elevation of alanine aminotransferase over 5 times the upper limit of the normal range, namely, obvious exacerbation. In these respects, there was no significant difference between observations before and after 1980 .

\section{Discussion}

As ID assay is less sensitive than RIA for detecting HBeAg, a significant decrease in the prevalence of $\mathrm{HBeAg}$ in the HBsAg carrier students in 1980-84 as compared with 1976-79 clearly denotes a recent actual decrease in HBeAg. Thus observations of serological markers in the university students showed a significant decrease in the prevalence of HBeAg in the HBsAg carrier students since 1980 as well as a significant decrease in the prevalence of anti-HBs in the first-year students since 1981. Though significant differences were observed only in male students, this may be ascribed, in case of the prevalence of HBeAg in the carrier students, to small number of the females. Decrease in the prevalence of $\mathrm{HBeAg}$ in the female carrier students in 1980-84 was more pronounced than males, and only $8 \%$ of the female HBsAg carrier students were positive for $\mathrm{HBeAg}$ in 1980 84.

There has been very few reports except our preliminary one (Nakamura 1983) which has concerned themself with a decrease in hepatitis B virus markers in Japan. In an isolated Canadian Inuit (Eskimo) settlement, however, evidence of hepatitis $\mathrm{B}$ virus infection ( $\mathrm{HBsAg}$, anti-HBs, and antibody to hepatitis B core antigen) is uncommonly low under the age of 20 as compared with adulthood, and it is suggested that a drastic decrease in the transmission of hepatitis B virus infection has occurred in the past (Minuk et al. 1982). Therefore, changes similar to those in this Canadian Inuit settlement seem to be now occurring or beginning to occur in the Japanese university students. Though the causes of these changes 
are not exactly known, improvement in medical practice, such as use of disposable needles and syringes, and in nutrition are considered.

\section{Acknowledgments}

We wish to thank Dr. F. Tsuda and Dr. M. Mayumi, Hepatitis Division of Tokyo Metropolitan Insititute of Medical Science, for determination of HBeAg and anti-HBe by ID and of subtypes of HBsAg.

\section{References}

1) Imai, M., Yamashita, Y., Miyakawa, Y. \& Mayumi, M. (1974) Hemagglutination inhibition assay of the common determinants and subspecificities of Australia antigen. Immunology, 27, 871-878.

2) Ise, I., Gotanda, R., Baba, K., Tsuda, F., Naito, S., Tachibana, K., Nakamura, T., Usuda, T., Imai, M. \& Nomura, M. (1982) Determination of subtypes of HBs antigen by solid phase RIA method. Acta hepatol. Jap., 23, 685. (Japanese)

3) Minuk, G.Y., Nicolle, L.E., Postl, B., Waggoner, J.G. \& Hoofnagle, J.H. (1982) $J$. med. Virol., 10, 255-264.

4) Nakamura, S. (1978) Chronic hepatitis B and Hepatitis B surface antigen carriers in university students. Tohoku J. exp. Med., 124, 391-392.

5) Nakamura, S, (1982) Serological markers of hepatitis A and B virus infection in university students. Tohoku J. exp. Med., 138, 237-238.

6) Nakamura, S. (1983) Decrease in female university students positive for hepatitis B e antigen. Tohoku J. exp. Med., 141, 123-124. 